\title{
The Need for Warrants Authorizing Foreign Intelligence Searches of American Citizens Abroad: A Call for Formalism
}

\author{
Justin M. Sandberg $\dagger$
}

Federal agents rush into a house in Kenya to search for information about a worldwide terrorist organization. This once-rare scenario figures prominently in the new, post-September 11 world, and it formed the facts of United States $v$ Bin Laden. ${ }^{1}$ In Bin Laden, the court held that a warrant is not required for a search by the United States government of an American citizen living abroad when the search is for foreign intelligence purposes. The court fit its decision under the rubric of the "foreign intelligence exception" to the Fourth Amendment's Warrant Clause. By deciding Bin Laden in this fashion, the court resurrected a long-dormant debate regarding the existence of the foreign intelligence exception, which applies to searches of agents of foreign powers for foreign intelligence information. ${ }^{4}$

The Warrant Clause of the Fourth Amendment ${ }^{s}$ has been interpreted to require the Executive to obtain a warrant based on probable cause prior to a search or seizure. The Supreme Court has long read this clause in conjunction with the first clause of the Fourth Amendment, yielding the rule that a search or seizure is unreasonable unless accompanied by a warrant. ${ }^{6}$ But the Court has recognized some exceptions to this rule.

$\dagger$ B.A. 1999, University of Notre Dame; I.D. Candidate 2002, The University of Chicago.

1 126 F Supp 2d 264 (S D NY 2000). The defendant in Bin Laden was Wadih El Hage, an alleged member of Usama Bin Laden's al Qaeda terrorist network. El Hage, an American citizen living in Nairobi, Kenya, had been indicted with other alleged al Qaeda operatives for the bombings of the U.S. embassies in Nairobi and Dar es Salaam, Tanzania.

2 Id at 277. For purposes of this Comment, unless otherwise noted, the term "search" refers to a search conducted by the United States Government.

3 Id at 277.

4 Id at 271.

5 US Const Amend IV ("[N]o Warrants shall issue, but upon probable cause.").

6 See Illinois $v$ McArthur, 531 US 326, 332-33 (2001) (holding that police officers did not violate the Fourth Amendment when they prevented a man from entering his house for two hours while they searched it).

7 See, for example, Ferguson $v$ City of Charleston, 121 S Ct 1281, 1288-92 (2001) (discussing exceptions to the warrant rule in certain drug-testing cases); Michigan Department of State Police v Sitz, 496 US 444, 455 (1990) (allowing suspicionless stops at drunk driver checkpoints); Michigan v Summers, 452 US 692, 705 (1981) (permitting temporary seizure to prevent flight and to protect officers executing a search warrant); Terry v Ohia, 392 US 1, 30 (1968) (upholding a temporary seizure and limited search for weapons). 
Prior to 1978, however, the Supreme Court remained agnostic regarding the foreign intelligence exception, and the circuit courts split on the issue. In a 1972 case, United States v United States District Court (Keith), the Court announced a generally applicable test for determining when there should be such an exception to the Warrant Clause. The test stated that courts should, among other things, look to see whether a warrant requirement would "unduly frustrate the efforts of Government to protect itself from acts of subversion and overthrow." ${ }^{10}$ The circuit courts applied this test and divided on one question: whether a foreign intelligence exception should apply to searches conducted domestically. ${ }^{11}$

In 1978, before the courts could resolve this matter, Congress passed the Foreign Intelligence Surveillance Act ("FISA"). " FISA creates a framework for issuing warrants in situations where the government seeks foreign intelligence information. ${ }^{13}$ Under FISA, no foreign intelligence search can occur until the President or the Attorney General issues a warrant and a special court, the Foreign Intelligence Surveillance Court, approves it. ${ }^{14}$ By its terms, however, FISA does not apply outside the borders of the United States. ${ }^{15}$

Arising outside of FISA's jurisdiction (the United States border), Bin Laden breathed new life into the debate regarding the foreign intelligence exception. No court before had addressed the constitutionality of a foreign intelligence search of an American citizen abroad. ${ }^{16}$ It is important to note that it is an open question whether the Fourth

807 US 297 (1972).

9 Id at 315.

10 Id.

11 Compare United States $v$ Truong, 629 F2d 908, 913 (4th Cir 1980) (holding that "a uniform warrant requirement would ... 'unduly frustrate' the President in carrying out his foreign affairs responsibilities"), quoting Keith, 407 US at 315; United States v Butenko, 494 F2d 593, 606 (3d Cir 1974) (holding that a prior judicial approval is not necessary when a search is conducted "solely for the purpose of gathering foreign intelligence information"); and United States $v$ Brown, 484 F2d 418, 426 (5th Cir 1973) (holding that "the President may constitutionally authorize warrantless wiretaps for the purpose of gathering foreign intelligence."); with Zweibon $v$ Mitchell, 516 F2d 594, 655 (DC Cir 1975) (finding that the President must receive judicial approval prior to conducting a wiretap of a domestic organization that was not collaborating with a foreign power). See also United States $v$ Buck, 548 F2d 871, 875 (9th Cir 1977) (holding that foreign security wiretaps "are a recognized exception to the general warrant requirement").

12 Foreign Intelligence Surveillance Act of 1978, Pub L No 95-511, 92 Stat 1783, codified at 50 USC §§ 1801-11 (1994 \& Supp 1999).

13 The original legislation did not contain provisions relating to physical searches. Those were added in 1994. See Intelligence Authorization Act for Fiscal Year 1995, Pub L No 103-359, 108 Stat 3443, codified at 50 USC $\$ \$ 1821-29$ (1994 \& Supp 1999).

1450 USC $\S 1822$ (a)-(c) (1994 \& Supp 1999). Under FISA, the Attorney General may issue warrants at the President's designation.

1550 USC \$ 1822(c).

16 Bin Laden, 126 F Supp 2d at 277. 
Amendment applies to any search of a United States citizen abroad. ${ }^{17}$ If the Fourth Amendment does not apply abroad, then the foreign intelligence exception is irrelevant because it would be swallowed up by a larger international exception to the Warrant Clause. After a cursory analysis, the Bin Laden court determined that the Fourth Amendment plausibly applied to American citizens abroad. ${ }^{18}$ Then, using the Keith framework, it ruled that there was no warrant requirement on account of the President's needs in conducting foreign policy. ${ }^{19}$

This Comment shows that the courts cannot properly apply the Keith standard because it forces them to make foreign policy assessments, a task for which they are unprepared and ill equipped. According to the current test, a court determines whether there is an exception to the Warrant Clause by deciding whether a warrant requirement would be an undue burden on the Executive's discharge of her duty to protect the nation against "subversion and overthrow." courts, however, are formally and functionally unfit to make such a foreign policy judgment.

Specifically, the courts lack the expertise and bureaucracy necessary to be considered competent in foreign affairs because the Constitution allocates this sphere of responsibility to the political branches. Due to this lack of competence, and the Executive's comparative expertise in foreign affairs, courts have been overly deferential to the Executive in cases involving foreign intelligence searches. In doing so, they have inadequately protected individual rights by abdicating their Fourth Amendment role as the neutral intermediary between the Executive and the citizenry.

17 Supreme Court case law, while ambiguous, suggests that the warrant requirement could be generally applicable. In Reid v Covert, 354 US 1 (1957), a plurality held that the Bill of Rights applies to U.S. citizens in foreign countries. Id at 6 . Moreover, the Court stated that it could find no reason to pick and choose among "the remarkable collection of "Thou shalt nots" when applying the Bill of Rights's limitations to U.S. government actions abroad. Id at 9. More recently, however, a plurality of the Court has stated that Reid implicated only the Fifth and Sixth Amendments and not the Fourth. United States $v$ Verdugo-Urquidez, 494 US 259, 270 (1990). In dicta, the court noted that the concurrences in Reid limited the plurality's sweeping language. Id. According to this reading, Reid holds only that "citizens stationed abroad could invoke the protection of the Fifth and Sixth Amendments." Id. Five members of the Court in Verdugo, however, did not join in this reasoning. Id at 277,282, 279,297 (Kennedy and Stevens concurring;Marshall, Brennan, and Blackmun dissenting). Given the heavily fractured nature of the Court, the precedential status of Verdugo is unclear. Compare United States $v$ Barona, 56 F3d 1087, 1093 (9th Cir 1995) (adopting Verdugo's narrow reading of Reid), with United States $v$ Boynes, 149 F3d 208, 211 (3d Cir 1998) (insisting that Reid is untouched because Verdugo is limited by its concurrences to noncitizens). Thus, Reid plausibly trumps Verdugo and provides the groundwork for the consideration of the application of the foreign intelligence exception overseas. See also Bin Laden, 126 F Supp 2d at 270.

18 Bin Laden, 126 F Supp 2 d at 270-71.

19 Id at 277 (finding "the power of the Executive to conduct foreign intelligence collection would be significantly frustrated by the imposition of a warrant requirement in this context").

20 Keith, 407 US at 315. 
Therefore, the courts should replace the current standard with a rule: a warrant is required for all foreign intelligence searches of American citizens abroad. By announcing a warrant rule, the courts could resolve the tension engendered by the Keith standard; they could protect individual rights without engaging in foreign policy analysis.

Doctrinally, this rule would fit into both the "new formalism" in foreign affairs law and existing Fourth Amendment jurisprudence. It would be more desirable than the opposite default rule-one that does not require a warrant for a foreign intelligence search abroadbecause it would comport better with the purposes of the Fourth Amendment. Moreover, judges could effectively administer this rule because they would only have to determine whether probable cause exists $^{22}$ - they would not have to predict the outcomes of international politics. Finally, a warrant issued for a foreign search would serve the same important Executive-limiting function that it serves for a domestic search.

In Part I, this Comment discusses the Keith standard and the circuit split surrounding its domestic application. Part I also briefly discusses the role FISA played in ending this debate domestically. Part II addresses the problem with using the Keith standard in Bin Ladentype cases, namely that courts are unable to apply the standard because they lack expertise in foreign policy. Finally, in Part III, this Comment suggests that the solution to the Keith problem is a brightline warrant rule because it extricates the courts from foreign policy considerations and allows them to focus on a legal question with which they are familiar-determining whether probable cause exists.

\section{THE KEITH STANDARD, THE CIRCUIT SPLIT, AND FISA'S SOLUTION WITH LIMITS}

\section{A. Keith: No Answer, but a Standard}

In Keith, the Court considered whether there was an exception to the Warrant Clause for domestic intelligence searches. ${ }^{23}$ The specific issue in Keith was whether the President, acting through the Attorney General, could "authorize electronic surveillance in internal security

21 See Jack Goldsmith, The New Formalism in United States Foreign Relations Law, 70 U Colo L Rev 1395, 1396-97 (1999).

22 In the foreign intelligence context, the traditional probable cause standard would have to be modified. Rather than looking for probable cause relating to a criminal offense, the court would look for probable cause that the target of the search has foreign intelligence information. See discussion in Part III.A.

23 The domestic intelligence search in Keith was aimed at material pertaining to the subversion and overthrow of the government but not involving foreign powers or their agents. Keith, 407 US at 308-09. 
matters without prior judicial approval., ${ }^{24}$ The Court said the President could not do so, but proclaimed that its holding left unanswered the foreign intelligence exception question. ${ }^{25}$ The Court did announce, however, a balancing test for determining whether there should be an exception to the Warrant Clause. In the end, the wording of this test determined the outcome of the foreign intelligence exception question.

1. The Keith Court refused to rule on the foreign intelligence exception.

The Supreme Court took great pains to distinguish the domestic intelligence exception at issue in Keith from a possible foreign intelligence exception. Early in the opinion, the Court argued that "the instant case requires no judgment on the scope of the President's surveillance power with respect to the activities of foreign powers, within or without this country." ${ }^{26}$ Later in the opinion, the Court again made a similar admonition: "We have not addressed, and express no opinion as to, the issues which may be involved with respect to the activities of foreign powers or their agents." ${ }^{27}$ The Court repeated itself to leave no doubt that the decision did not reflect its view of the propriety of a foreign intelligence exception.

\section{The announcement of a determinative standard.}

While explicitly refusing to let its holding in Keith dictate the future of the foreign intelligence exception, the Court formulated a balancing test that did just that. Used to determine whether there should be an exception to the warrant requirement, the test stated:

As the Fourth Amendment is not absolute in its terms, our task is to examine and balance the basic values at stake in this case: the duty of Government to protect the domestic security, and the potential danger posed by unreasonable surveillance to individual privacy and free expression. If the legitimate need of Government to safeguard domestic security requires the use of electronic surveillance, ${ }^{23}$ the question is whether the needs of citizens for privacy and free expression may not be better protected by

\footnotetext{
Id at 299.

Id at 308.

Id.

Id at 321-22.

28 Electronic surveillance and physical searches have been taken to be equally intrusive: "Though physical entry of the home is the chief evil against which the wording of the Fourth Amendment is directed, its broader spirit now shields private speech from unreasonable surveil-
} lance." Id at 313. 
requiring a warrant before such surveillance is undertaken. We must also ask whether a warrant requirement would unduly frustrate the efforts of Government to protect itself from acts of subversion and overthrow directed against it. ${ }^{29}$

Earlier in the opinion, the Court derived the duty to protect domestic security from the President's oath to "preserve, protect and defend the Constitution,", which implicitly directs the President "to protect our Government against those who would subvert it or overthrow it by unlawful means." ${ }^{31}$

Against this duty, the Court purported to weigh the rights of the individual to free expression and privacy, embodied in the First and Fourth Amendments, respectively. ${ }^{32}$ The First Amendment was relevant because of the specific facts of Keith. ${ }^{33}$ In pure Fourth Amendment terms, then, the Court was supposed to balance the President's duty to protect the government against the individual's right to privacy. But the Court's phrasing of the rights portion of the test stripped it of any practical meaning: "[T]he question is whether the need of citizens for privacy ... may not be better protected by requiring a warrant before such surveillance is undertaken." ${ }^{\text {,4 }}$ There was no question there. The Court has long held that the citizen's right to privacy benefited from the protection of a warrant. ${ }^{35}$ Thus, this part of the test was a non-factor-the real moving parts were housed elsewhere.

The last line, asking "whether a warrant requirement would unduly frustrate the efforts of Government to protect itself from acts of subversion and overthrow directed against it, ${ }^{36}$ drove this test. In determining whether there should be an exception in this case, the Court looked exclusively to factors that could cause the Executive to suffer an undue burden. ${ }^{37}$ And while the Court acknowledged that the war-

29 Id at 314-15.

30 US Const Art II, \& 1, cl 8.

31 Keith, 407 US at 310.

32 Id at 313-14.

33 Keith involved the surveillance of telephone conversations (speech), and there was a concern that the domestic security search was part of a program to punish the defendants merely for "unorthodoxy in their political beliefs." Keith, 407 US at 314.

34 Id at 315.

35 See United States $v$ Watson, 423 US 411, 445 (1976) (Marshall dissenting) ("Of course the privacy of our citizens will be better protected by a warrant requirement."); Chimel $v$ California, 395 US 752,761 (1969) (finding that a search of the defendant's house without a search warrant violated his constitutional rights); McDonald v United States, 335 US 451, 455-56 (1948) ("The Constitution requires a magistrate to pass on the desires of the police before they violate the privacy of the home."); Johnson v United States, 333 US 10,14 (1947) ("When the right of privacy must reasonably yield to the right of search ... is to be decided by a judicial officer, not by'a policeman or government enforcement agency.").

36 Keith, 407 US at 315.

37 First, the Court considered (and dismissed) the claim that a warrant was not necessary because the surveillance at stake in this case was aimed primarily at obtaining intelligence data, 
rant requirement would somewhat burden the Executive, it held that the requirement would not impose an undue burden: "[T]his inconvenience is justified in a free society to protect constitutional values.",3

In sum, Keith stands for two important points. First, the holding in Keith did not dictate, per se, the outcome of the foreign intelligence exception question. Second, the Court introduced a balancing test for determining whether there should be an exception to the warrant requirement that, as written, determined the outcome of this question. ${ }^{39}$

\section{B. The Circuit Split}

After Keith, four circuits-the Third, Fourth, Fifth, and Ninthdecided that there was a foreign intelligence exception to the warrant requirement for searches conducted in the United States. ${ }^{40}$ The D.C. Circuit came to the opposite conclusion. ${ }^{41}$ As would be expected in the wake of Keith, presidential power took center stage in the decisions from both sides of the divide. The four circuits that upheld the exception believed a warrant requirement would impose an undue burden on the President. The D.C. Circuit, on the other hand, thought a warrant should be required for foreign intelligence gathering, just as it was for domestic intelligence gathering.

1. The Third, Fourth, Fifth, and Ninth Circuits found a domestic foreign intelligence exception.

The Third Circuit, in United States $v$ Butenko, ${ }^{42}$ upheld a warrantless foreign intelligence search based on the President's need for

not at obtaining evidence for criminal prosecutions. Second, the Court rejected the claim that the courts lack the ability to determine when there is probable cause to believe that surveillance is necessary to protect national security. Finally, the Court dismissed the idea that introducing the courts into intelligence matters increases the possibility of "security leaks." Id at 318-21.

38 Id at 321.

39 The second point is obviously important. The first point is important because the Court recognizes that it is relatively less competent to decide on the foreign intelligence exception than the domestic intelligence exception, and because it leaves the courts of appeals room to institute the warrant requirement suggested by this Comment.

40 United States v Truong, 629 F2d 908, 913 (4th Cir 1980) (allowing a warrantless search for foreign intelligence information); United States v Buck, 548 F2d 871, 875 (9th Cir 1977) (recognizing the foreign security exception to the general warrant requirement for wiretaps); United States v Butenko, $494 \mathrm{~F} 2 \mathrm{~d}$ 593, 606 (3d Cir 1974) (holding that prior judicial approval is unnecessary for the purpose of gathering foreign intelligence information); United States $v$ Brown, 484 F2d 418, 426 (5th $\mathrm{Cir}$ 1973) (holding that the President may authorize warrantless wiretaps for foreign intelligence gathering).

41 Zweibon v Mitchell, 516 F2d 594, 655 (DC Cir 1975) (en banc) (holding that the Constitution requires the President to seek prior authorization to wiretap a domestic organization that is not an agent of a foreign state).

42494 F2d 593 (3rd Cir 1974). In this case the defendant, a Soviet national, claimed that his Fourth Amendment rights were violated by warrantless electronic searches conducted in the United States, and that this information therefore tainted his conviction. Id at 596-97. 
flexibility and speed in foreign intelligence gathering. ${ }^{43}$ Specifically, the court noted that a warrant requirement would impinge on the flexibility to conduct these operations because "foreign intelligence gathering is a clandestine and highly unstructured activity ... [that] often cannot be anticipated in advance." ${ }^{44}$ Moreover, a warrant requirement would slow down intelligence operations because it would require those gathering the intelligence to "interrupt their activities and rush to the nearest available magistrate to seek a warrant."

In United States $v$ Truong, ${ }^{46}$ the Fourth Circuit permitted warrantless foreign intelligence searches because "the needs of the Executive are so compelling in foreign intelligence, unlike the area of domestic security, that a uniform warrant requirement would, following Keith, 'unduly frustrate' the President in carrying out his foreign affairs responsibilities." ${ }^{47}$ Specifically, the Executive needs to use his flexibility, speed, secrecy, expertise, and constitutional competence. ${ }^{43}$ Flexibility, speed, and secrecy would be compromised by a warrant requirement because it would present a procedural hurdle for the Executive and it would increase the chance of leaks. The court also argued that "the Executive possesses unparalleled expertise" that the judiciary lacks because the President has a specialized bureaucracy that keeps him informed about foreign affairs. ${ }^{\text {so }}$ Finally, the court noted that the Executive is "constitutionally designated as the preeminent authority in foreign affairs." "si

The Fifth Circuit, in United States $v$ Brown, ${ }^{52}$ found dispositive the President's inherent power with respect to conducting foreign affairs, holding that the President has the authority to conduct warrantless searches over and above the Warrant Clause of the Fourth Amendment. ${ }^{53}$ The logic of this decision flowed from the idea that the President's powers in foreign affairs are extraconstitutional. ${ }^{\text {st }}$ The Ninth

43 Id at 605.

44 Id.

45 Id.

$46 \quad 629$ F2d 908 (4th Cir 1980). The defendants in this case sought to overturn their espionage convictions because of warrantless searches and seizures. Id at 911 .

47 Id at 913.

48 Id at 913-15.

49 Id at 913.

50 Id at $913-14$.

51 Id at 914.

52 484 F2d 418 (5th Cir 1973). The defendant in this case sought to overturn his conviction because it was based on information obtained in warrantless wiretaps designed to collect foreign intelligence information. Id at 425-26.

53 Id at $425-27$.

54 Id. This position, associated with United States $v$ Curtiss-Wright Export Corp, 299 US 304, 318 (1936), has been derogated by a member of the Court and rejected by academics. See Youngstown Sheet \& Tube Co v Sawyer, 343 US 579, 635-36 n 2 (1952) (Jackson concurring) (referring to the inherent power portion of Curtiss-Wright as "dictum"); Jack L. Goldsmith, Federal 
Circuit adopted, without much discussion, the reasoning of this and the Third Circuit's decisions.

2. The D.C. Circuit denied the existence of the domestic foreign intelligence exception.

The D.C. Circuit's plurality holding in Zweibon v Mitchell ${ }^{56}$ stood on the other side of the circuit split. In Zweibon, a suit for damages, the court held that there was no foreign intelligence exception when the government searched citizens in the United States who were neither agents of a foreign government nor acting for a foreign power. ${ }^{57}$ But in dicta the court went further. The four-member plurality concluded that nothing inherent in foreign intelligence matters suggests that "a warrant procedure would actually fetter the legitimate intelligence gathering functions of the Executive Branch." on to say that, absent exigent circumstances, no foreign intelligence search should be conducted without a search warrant. ${ }^{59}$

In reaching its conclusion, the court rejected the arguments the other circuits forwarded in favor of the exception. The court dismissed the Third and Fourth Circuits' speed and flexibility arguments as claims for the already existing exigent circumstances exception. ${ }^{60}$ In renouncing the Fourth Circuit's secrecy argument, the court argued that Keith put it aside in the domestic intelligence context, and it is no more persuasive in the foreign intelligence context. ${ }^{61}$ The court rejected the expertise rationale because the Executive has always been willing to allow the post hoc review of searches by courts, and there is no reason to believe that courts would be any more competent to conduct a review after a search rather than before it. ${ }^{62}$

The court repudiated the Fourth Circuit's constitutional allocation argument and the Fifth Circuit's "inherent power" argument by asserting that a case is not beyond the ken of the judiciary simply because it touches on foreign affairs. ${ }^{63}$ The question of the foreign intelli-

Courts, Foreign Affairs, and Federalism, 83 Va L Rev 1617,1659 (1997) (describing Curtiss-Wright as "the bête noire of U.S. foreign relations law"); Michael J. Glennon, Two Views of Presidential Foreign Affairs Power: Little v. Barreme or Curtiss-Wright?, 13 Yale J Intl L 5, 13 (1988) ("[The majority opinion] in Curtiss-Wright is a muddled law review article wedged with considerable difficulty between the pages of the United States Reports.").

55 United States v Buck, 548 F2d 871, 875-76 (9th Cir 1977).

56516 F2d 594 (DC Cir 1975) (en banc).

57 Id at 614.

58 Id at 651 .

59 Id.

60 Id at 649-50.

61 Id at 647.

62 Id at 644-45.

63 Id at 623 ("Yet it is error to suppose that every case or controversy which touches on foreign relations lies beyond judicial cognizance."'), quoting Baker v Carr, 369 US 186, 211 
gence exception lies within the judiciary's expertise because it involves "providing a bulwark against Executive excess, a task which the Fourth Amendment deliberately allocated to the neutral officials of the judiciary." ${ }^{\infty}$

\section{FISA: A Solution with Limits}

Before the Supreme Court could resolve this circuit split, Congress passed FISA in 1978. FISA requires the Executive to obtain a warrant for foreign intelligence searches conducted in the United States. ${ }^{\text {os }}$ Under FISA, no foreign intelligence search can occur until the President (or the Attorney General) issues a warrant, and a special court, the Foreign Intelligence Surveillance Court, approves it. ${ }^{60}$ Thus, the passage of FISA resolved the question at the heart of the circuit split. But, it left a gaping hole in the law-all searches that lay beyond the United States border.

\section{BIN LADEN AND THE KEITH STANDARD: FOREIGN POLICY CONSIDERATIONS AND THE SACRIFICING OF THE FOURTH AMENDMENT}

Bin Laden resurrected the debate over the foreign intelligence exception by arising outside of FISA's territorial limits. In doing so, it revived Keith's undue burden standard. As the arguments in Bin Laden show, this standard pushes courts outside of their proper role by forcing them to consider questions of foreign policy. Understandably reluctant to venture into foreign policy, the courts have been overly deferential to the Executive. As a result, they have inadequately protected individual rights.

\section{A. Bin Laden and the Keith Standard}

In Bin Laden, the defendant, an American citizen reputed to be part of Osama Bin Laden's terrorist organization, sought to suppress evidence seized by United States agents in a search of his house in Kenya based on the absence of a warrant. ${ }^{67}$ The Government argued that the search fell within the foreign intelligence exception because it was aimed at foreign intelligence information held by an agent of a foreign power. ${ }^{63}$ After acknowledging the novelty of the issue, the

\footnotetext{
(1962).

64 Id at 624.

65 See FISA, 50 USC $\S 1801$. See also notes $12-15$ and accompanying text.

66 Id.

67 Bin Laden, 126 F Supp 2d at 269.

68 Id at 271 . The court relies on the definitions of "agent" and "foreign power" contained in FISA. Id at 278. The applicable definition of agent is a person who "knowingly engages in sabo-
} 
court determined that the foreign intelligence exception applied overseas because of the President's power over foreign affairs, the costs of imposing a warrant requirement, the force of precedent, and the absence of a warrant procedure abroad. ${ }^{69}$

In its conclusion, the court revealed that the Keith standard stood behind its decision: "The [c]ourt finds that the power of the Executive to conduct foreign intelligence collection would be significantly frustrated by the imposition of a warrant requirement in this context." ${ }^{70}$ Also, earlier in the opinion, the court cited Keith for the proposition that a warrant should not be required if it is a disabling burden on the Executive. ${ }^{71}$ The Bin Laden court's arguments reveal the problem with this standard.

\section{B. The Keith Standard Requires Courts to Consider Foreign Policy}

The Keith standard is so broad that it forced the Bin Laden court to consider issues of foreign policy. Twice the court cited Chicago \& Southern Airlines, Inc $v$ Waterman Steamship Corp ${ }^{n}$ for the proposition that "the judiciary should not interfere with the 'delicate' and 'complex' decisions of foreign policy which are 'wholly confided by the Constitution to the political departments of the government, Executive and Legislative." "'73 It appears that the court wanted to avoid imposing a warrant requirement because it believed the case raised a foreign policy question. The court's decision to quote United States $v$ Curtiss-Wright Export Corp ${ }^{74}$ for the proposition that the President is supreme in "the field of international relations" court's belief that the question, as framed by Keith, was one of foreign policy. Later in the opinion, the court quoted the Government's argument that the court would have a hard time determining the "international consequences flowing from a decision on the merits' [sic] regarding Executive Branch foreign policy decisions., ${ }^{, 76}$ The court then indicated its specific foreign policy concern about deciding whether or not to institute a warrant requirement: "Often these decisions have significant impacts on the essential cooperative relationships between

\footnotetext{
tage or international terrorism, or activities that are in preparation therefore, or on behalf of a foreign power." 50 USC $\$ 1801(\mathrm{~b})(2)(C)$. The relevant definition of a foreign power is "a group engaged in international terrorism or activities in preparation therefore." 50 USC $\$ 1801(\mathrm{a})(4)$.

69 Bin Laden, 126 F Supp 2d at 271-78.

70 Id at 277.

71 Id at 273-74.

72333 US 103 (1948).

73 Bin Laden, 126 F Supp 2d at 272, 274.

74299 US 304 (1936).

75 Bin Laden, 126 F Supp 2d at 272.

76 Id at 274.
} 
United States officials and foreign intelligence services." ${ }^{n}$ Cooperative relations with other nations are, after all, the lodestar of foreign policy. ${ }^{78}$

Other courts have also interpreted the Keith standard to require an assessment of foreign policy issues. In Truong, the court said, "The President and his deputies are charged by the constitution with the conduct of the foreign policy of the United States in times of war and peace." ${ }^{79}$ This statement shows that the court here, as in Bin Laden, considered the decision of whether to require a warrant a foreign policy one. Brown, by citing Chicago \& Southern Airlines for the same policy proposition Bin Laden did (namely, that the President has inherent authority to conduct foreign affairs), demonstrated that it too categorized the decision as one of foreign policy. ${ }^{80}$ Finally, the Butenko court thought foreign policy dictated the decision to permit warrantless foreign intelligence searches, writing that there is "strong public interest" in the "efficient operation of the Executive's foreign policy." ${ }^{, 81}$

The Zweibon court, the foil in the circuit split, seemed to discount the necessity of making a foreign policy decision in order to apply the Keith standard. Obviously, the court was aware that this case involved foreign policy at various levels. ${ }^{22}$ But, unlike the courts on the other side of the circuit split, it did not consider whether it was competent to apply the Keith test given its inherent foreign policy element. Though the outcome of this decision may be normatively desirable, it arises either from a mistaken interpretation of the Supreme Court's test in Keith or a willful disregard of its dictates. Neither path is acceptable. The functioning of the judiciary depends on the lower courts' faithful adherence to Supreme Court precedent.

77 Id.

78 Though perhaps changing, this has long been the case because nation-states have been the only recognized actors on the international stage. Karsten Nowrot, Legal Consequences of Globalization: The Status of Non-Governmental Organizations under International Law, 6 Ind J Global Legal Stud 579,620-21 (1999) (recognizing that traditionally only states were the actors on the international scene); Gregory G.A. Tzeutschler, Corporate Violator: The Alien Tort Liability of Transnational Corporations for Human Rights Abuses Abroad, 30 Colum Hum Rts L Rev 359,387 (1999) ("[T]he international legal system has not traditionally recognized non-state actors.").

79 Truong, $629 \mathrm{~F} 2 \mathrm{~d}$ at 914.

80 Brown, 484 F2d at 426.

81 Butenko, $494 \mathrm{~F} 2 \mathrm{~d}$ at 605.

82 Most pertinent for this Comment may be the fact that the court considered whether the President alone was competent to make the decision to conduct a search abroad because of the foreign affairs content. Zweibon, 516 F2d at 619-24.

83 Thurston Motor Lines, Inc v Jordan K. Rand, Ltd, 460 US 533, 535 (1983) ("[N]eedless to say, but only this Court may overrule one of its own precedents."); Hutto v Davis, 454 US 370, 375 (1982) ("[U]nless we wish anarchy to prevail in the federal judicial system, a precedent of this Court must be followed by the lower federal courts no matter how misguided the judges of 


\section{Courts Are III Suited to Decide Foreign Policy Issues}

Both textual and functional considerations indicate that the political branches rather than the courts should make foreign policy decisions. The textual arguments arise out of the Constitution, which allocates the power to conduct foreign affairs to the political branches and not to the judiciary. ${ }^{84}$ Under the Constitution, the Executive has the power to act as the Commander-in-Chief, ${ }^{s s}$ make and ratify treaties, ${ }^{26}$ appoint ambassadors, ${ }^{87}$ and recognize foreign nations. ${ }^{88}$ Congress also has considerable foreign affairs powers under the Constitution, including the power to regulate commerce with foreign nations, ${ }^{89}$ to define and punish crimes committed on the high seas and offenses against the law of nations, ${ }^{20}$ to declare war, ${ }^{91}$ and to raise and support armies and navies. ${ }^{2}$ On the other hand, no provision of the Constitution grants the judiciary foreign affairs powers. ${ }^{93}$ But there is also no provision that explicitly excludes the courts from foreign affairs. Thus, the textual argument for the inappropriateness of judicial decisionmaking in the realm of foreign affairs is strong, but not conclusive.

Functional arguments complete the job started by the textual ones." Courts are functionally ill-suited to decide foreign policy ques-

those courts may think it to be.").

84 While a bare enumeration of powers makes the political branches appear to be on equal footing in foreign affairs, the conventional wisdom is that the Executive has more power because of the structure of the branches. The structure is said to favor the Executive, because Congress, though it has foreign relations expertise and information, is "too diffuse, too public, and too deliberative to perform many foreign relations tasks." Goldsmith, 70 U Colo L Rev at 1398 (cited in note 21).

85 US Const Art II, $\$ 2, \mathrm{cl} 1$.

$\$ 6$ Id, $\$ 2, \mathrm{cl} 2$.

87 Id.

88 Id, $\$ 3$. The power to receive ambassadors includes the power to recognize foreign nations. See, for example, Goldwater v Carter, 481 F Supp 949, 961 (D DC 1979).

89 US Const Art I, § 8, cl 3 .

90 Id, § 8, cl 10.

91 Id, § 8, cl 11.

92 Id, \& 8, cls 12-13.

93 The Constitution's grant of jurisdiction to the federal courts to hear cases involving the high seas, ambassadors, and citizens from other states appears to grant the federal courts foreign affairs power. US Const Art III, $\S 2$. But this provision was aimed primarily at keeping the states out of foreign affairs. Beth Stephens, The Law of Our Land: Customary International Law as Federal Law After Erie, 66 Fordham L Rev 393, 406 (1997) (remarking that the Framers assigned jurisdiction to cases touching on foreign affairs to federal courts in order to ensure national control over foreign affairs). See Baker v Carr, 369 US 186, 211 (1962) (noting that a case does not involve making foreign policy simply because it touches on foreign affairs).

94 These arguments are related, of course, because the superior functionality of the political branches comes, in part, from the system set up by the text. But they are distinct arguments because the text does not fully describe our government; it does not, for example, explicitly provide for the administrative state. So, in addition to the text of the Constitution, one must analyze the practical workings of the government to understand the power relationships between the branches. 
tions because they lack the ability to identify foreign relations interests. The conventional wisdom is that the courts lack two important resources for this task: information and expertise. ${ }^{96}$ First, courts do not have access to the kind of foreign intelligence information-reports of the intelligence agencies, the State Department, and the Department of Defense-to which the political branches have access." Second, courts do not have the same informed bureaucracies dedicated to foreign affairs that the Executive (for example, the State Department and the CIA) and Congress (for example, committee and subcommittee staff) possess. ${ }^{93}$ Because of these deficiencies, the courts lack the ability to identify the foreign relations interests of the United States, an "enormously complex endeavor" and a necessary step in making foreign policy decisions."

\section{Courts Defer to the Executive under Keith Because They Are Aware of Their Relative Incompetence in Foreign Policy}

Courts pondering the existence of the foreign intelligence exception have acknowledged their relative incompetence in foreign policy. The Bin Laden Court approvingly noted, "It has been asserted that the judicial branch is ill-suited to the task of overseeing the foreign intelligence collection." ${ }^{100}$ In Keith, the Supreme Court implied that courts are relatively inexperienced in foreign policy by repeatedly distinguishing the question of the domestic intelligence exception from the foreign intelligence exception. ${ }^{101}$ The Fourth Circuit was more explicit: "[T]he executive branch not only has superior expertise in the area of foreign intelligence, it is also constitutionally designated as the pre-eminent authority in foreign affairs." ${ }^{102}$ Similarly, in Brown, the Fifth Circuit wrote, "[I]t would be intolerable that courts, without the

95 The court in Keith, 407 US at 309, did not encounter this problem because that case (with its domestic setting and parties) did not require an assessment of foreign policy.

96 Goldsmith, 70 U Colo L Rev at 1398 (cited in note 21) ("[The courts] lack the information, expertise, unity, and national political accountability to make foreign relations judgments for the nation.").

97 Chicago \& Southern Airlines, 333 US at 111.

98 See id (discussing the judiciary's lack of "aptitude, facilities[, and] responsibility" for foreign policy decisions and, by implication, the political branches' more abundant resources in this area).

99 Goldsmith, $70 \mathrm{U}$ Colo L Rev at 1415 (cited in note 21).

100 Bin Laden, 126 F Supp 2d at 274.

101 Keith, 407 US at 308, 321-22. The Court explicitly expressed an understanding of its relative incompetence in foreign policy in Itel Containers International Corp v Huddleston, 507 US 60,76 (1993) (noting that "the nuances of foreign policy 'are much more the province of the Executive Branch and Congress than of this Court"') (citation omitted).

102 Truong, 629 F2d at 914. 
relevant information, should review and perhaps nullify actions of the Executive taken on information properly held secret." ${ }^{\text {"13 }}$

Because the courts are conscious of their inability to consider adequately the implications of foreign policy, they defer to the Executive. The Executive's win-loss record in foreign intelligence exception cases is one indication of the courts' deference to the Executive. In every case that required a determination of the validity of the exception (Butenko, ${ }^{104}$ Truong, ${ }^{105}$ Brown, ${ }^{106}$ United States $v$ Buck, ${ }^{107}$ Bin Laden $\left.^{103}\right)$, the Executive won. In Zweibon, the court denied the existence of the exception, but it did so in dictum, ${ }^{109}$ and did not consider the policy implications in the same way. ${ }^{10}$

More pointedly, the Executive won because the courts deferred to the Executive's superior competence in foreign policy: "The executive possesses unparalleled expertise to make the decision whether to conduct foreign intelligence surveillance." $\mathrm{Orl}$, as the court in $\mathrm{Bu}$ tenko starkly put it, courts could impose a warrant requirement, but "the better course is to rely, at least in the first instance, on the good faith of the Executive."112 Brown's deference was equally clear. According to Brown, courts have no place constraining the Executive because she has authority in foreign affairs "over and above the Warrant Clause of the Fourth Amendment." Implicit in this statement is the notion that authority originating outside the Constitution arises outside the Court's ability to limit it. ${ }^{114}$ The court in Bin Laden deferred more subtly but no less importantly than the Butenko and Brown courts, making repeated references to the superior competence of the Executive in foreign policy matters. ${ }^{115}$

103484 F2d at 426 (internal quotation marks omitted), quoting Chicago \& Southern Airlines, 333 US at 111.

$104494 \mathrm{~F} 2 \mathrm{~d}$ at 608.

105629 F2d at 914.

$106484 \mathrm{~F} 2 \mathrm{~d}$ at 426.

107548 F2d 871, 875 (9th Cir 1977).

$108126 \mathrm{~F}$ Supp $2 \mathrm{~d}$ at 277.

109516 F2d at 651.

110 See Part II.C.

111 Truong, 629 F2d at 913.

$112494 \mathrm{~F} 2 \mathrm{~d}$ at 605.

113484 F2d at 426.

114 This argument for presidential power goes even further than the one proffered in the oft-criticized Curtiss-Wright opinion. See Curtiss-Wright, 299 US at 320 (noting that even the President's extraordinary foreign affairs power "must be exercised in subordination to the applicable provisions of the Constitution"). See note 54.

115 Bin Laden, 126 F Supp 2d at 272-74. 


\section{E. Judicial Deference Means That Individual Rights Are Insufficiently Protected}

Citizens should greet with apprehension the courts' decisions to defer to the Executive on the Fourth Amendment question of whether to institute a warrant requirement for foreign intelligence searches. The Constitution interposes the courts between the Executive and the citizenry in order to guard individuals from executive excess in searches and seizures. ${ }^{116}$ Judicial deference to the Executive on foreign policy issues is normally desirable because the Executive is more competent than the courts in foreign affairs and thus more likely to make the right decision. In this case, however, deference on the foreign policy issue requires deference on a Fourth Amendment issuewhether to issue a warrant-that the Constitution purposefully gives to the courts. If the courts defer to the Executive on this latter question, they fail the American people (and the Fourth Amendment) by abdicating their responsibility to limit the Executive's discretion.

In Keith, the Court discussed the interposition of the courts between the Executive and the citizenry. It cited approvingly Lord Mansfield, who wrote, "It is not fit ... that the receiving or judging of the information should be left to the discretion of the officer. The magistrate ought to judge; and should give certain directions to the officer." $"$ "The Court then continued: "[I]nherent in the concept of a warrant is its issuance by a 'neutral and detached magistrate." der the Fourth Amendment, members of the executive branch do not count as disinterested magistrates because they are responsible for enforcing the laws through investigation and prosecution."

When the courts abdicate their Fourth Amendment responsibility, executive excess threatens individual liberty. The Constitution positions the courts between the Executive and the people in order to en-

116 See Johnson $v$ United States, 333 US 10, 13-14 (1947) (holding that the Fourth Amendment's protection lies in shifting decisions to neutral judicial officers).

117 Keith, 407 US at 316.

118 Id at 317, quoting Coolidge v New Hampshire, 403 US 443, 453 (1971).

119 Id. Some, such as the Bin Laden court, argue that post-search review substantially fulfills the Fourth Amendment goals served by pre-search warrants. Bin Laden, 126 F Supp at 277. But other courts have persuasively argued that post-search review serves as an inadequate proxy for pre-search warrants, giving three reasons. First, it leaves the decision to search, in the first instance, in the hands of the executive. See United States $v$ Diggs, 544 F2d 116, 130 n 18 (3d Cir 1976) (noting that a neutral magistrate is "better able than those with personal interests at stake" to make a decision about a search warrant). Second, it does not protect "against hindsight justification" by government agents. Id. Third, post-search review only applies to searches in which a criminal prosecution is brought by the state or in which a civil suit is brought against the state by a target of a search; it fails in all other cases. See Keith, 407 US at 318 (explaining that postsearch review fails to reach cases that do not result in prosecution). See also Latta v Fitzharris, $521 \mathrm{~F} 2 \mathrm{~d} 246,257$ (9th Cir 1975) (expressing concerns about executive discretion and post hoc justifications in the absence of a warrant requirement). 
sure that each search is reasonable and limited. ${ }^{120}$ The rationale is simple: if the Executive, a partisan, can convince a judge, a neutral party, that a search is reasonable, then the chances are better, objectively speaking, that the search is reasonable. ${ }^{121} \mathrm{Or}$, as the Court eloquently put it, warrants operate "as a matter of course 'to check the wellintentioned but mistakenly over-zealous executive officers' who are a part of any system of law enforcement.",22

The Fourth Amendment is too important to sacrifice. In Coolidge $v$ New Hampshire, ${ }^{123}$ the Court used soaring language to synthesize its previous decisions on the Fourth Amendment:

The effect of the decisions is: that such rights are declared to be indispensable to the 'full enjoyment of personal security, personal liberty and private property'; that they are to be regarded as of the very essence of constitutional liberty; and that the guaranty of them is as important and as imperative as are the guaranties of the other fundamental rights of the individual citizen. ${ }^{124}$

Given the importance of the Fourth Amendment, and the central role the courts play in protecting it, deference to the Executive in foreign intelligence exception cases is unacceptable: "Prior review by a neutral and detached magistrate is the time-tested means of effectuating Fourth Amendment rights."

\section{THE ANSWER TO THE KEITH PROBLEM:A WARRANT RULE}

The courts should exchange the Keith standard for a rule requiring a warrant for foreign intelligence searches of American citizens abroad. This rule would obviate the problem of possible judicial incompetence in foreign affairs, instead allowing courts to rely on a core area of competence-the application of law to fact. In addition, it would track the purposes of the Fourth Amendment. Finally, by cabin-

120 United States v Verdugo-Urquidez, 494 US 259, 296 (1990) (Brennan dissenting) (stating that the warrant requirement "assures that a neutral magistrate has authorized the search and limited its scope").

121 Id at 295.

122 Coolidge $v$ New Hampshire, 403 US 443, 481 (1971), quoting Gouled $v$ United States, 255 US 298, 304 (1921).

123403 US 443 (1971).

124 Id at 454, n 4, quoting Gouled, 255 US at 303-04. The use of this quotation from Coolidge is not intended to convey the idea that the privacy protected by the Fourth Amendment is so sacrosanct that a balancing test may never be used. See Tracey L. Meares and Bernard E. Harcourt, Foreword: Transparent Adjudication and Social Science Research in Constitutional Criminal Procedure, $90 \mathrm{~J}$ Crim L \& Criminol 733, 741 (2000) (recognizing that rights-oriented liberals "take issue with the idea of balancing liberty interests against the interests of law enforcement in formulating the scope of constitutional rights" because they view "rights as trumps").

125 Keith, 407 US at 318. 
ing executive discretion, a warrant rule would serve the same important function abroad that it serves domestically.

A. The Warrant Rule Would Obviate the Problem of Judicial Involvement in Foreign Policy

A rule requiring a court to issue a warrant before the Executive could conduct a search abroad would avert the problem of judicial incompetence in foreign policy. A court in this position would not have to be competent in foreign policy because it would not have to engage in an independent analysis of the effects of its decision on the United States' foreign affairs. "By specifying the content of federal law prior to the point of judicial decision," ${ }^{\text {,26 }}$ this new rule would fit comfortably into what has been termed "the new formalism" in foreign affairs law. ${ }^{127}$ New formalism is the term used to describe the Supreme Court's trend of replacing standards with rules that limit the courts' responsibility to make foreign policy decisions. ${ }^{128}$

In Barclays Bank PLC v Franchise Tax Board of California, ${ }^{129}$ for example, corporate taxpayers challenged California's worldwide combined reporting requirement for the calculation of a franchise tax under the Commerce Clause because it was likely to "provoke retaliatory action by foreign governments." this challenge and with it the foreign relations effects tests it had previously applied to such claims. ${ }^{131}$ The Court explained that foreign policy nuances were the province of the Executive and Congress, not the courts. ${ }^{132}$ Thus, it instead relied, in rule-like fashion, on the lack of a federal law preempting state action. ${ }^{133}$ Since none had done so, the state's action was valid because Congress, not the Court, has the responsibility to strike the balance between international relations risks and state autonomy. ${ }^{134}$ The Court presumed validity in the face of Congressional silence.

126 Goldsmith, 70 U Colo L Rev at 1424 (cited in note 21).

127 Id at 1395.

128 Id at 1395. See, for example, Barclays Bank PLC v Franchise Tax Board of Cal, 512 US 298,321-31 (1994) (requiring express action by Congress to preempt state action that implicated foreign affairs); EEOC v Arabian American Oil Co, 499 US 244, 249-59 (1991) (requiring an express statement by Congress to find that a statute applies extraterritorially), superseded by the Civil Rights Act of 1991, Pub L No 102-166, 105 Stat 1071, codified at 42 USC $\$ 2000$ e(f) (1994); W.S. Kirkpatrick \& Co v Environmental Tectonics Corp, 493 US 400, 408-10 (1990) (refusing to apply the act of state doctrine in a case that did not involve validity of a foreign sovereign's act).

129512 US 298 (1994). For a discussion of Barclays in the context of the "new formalism," see Goldsmith, 70 U Col L Rev at 1425-27 (cited in note 21).

130 Barclays, 512 US at 328.

131 Goldsmith, 70 U Colo L Rev at 1426 (cited in note 21).

132 Barclays, 512 US at 327-28.

133 Id at 326-28.

134 Id at 330-31 ("[W]e leave it to Congress-whose voice, in this area, is the Nation's - to 
In W.S. Kirkpatrick \& Co v Environmental Tectronics Corp, ${ }^{136}$ to take another example, Environmental Tectronics claimed that Kirkpatrick had obtained a contract with the Nigerian Government by bribing Nigerian officials. ${ }^{137}$ In its defense, Kirkpatrick raised the act of state doctrine which precludes courts from "passing on the validity of foreign acts of state" because this "may hinder the conduct of foreign affairs." of a decision in this case, and had reached opposite results. ${ }^{139}$ The Supreme Court, however, rejected this approach and avoided deciding any fine-grain foreign relations matters by "establishing a scopelimiting rule like preliminary inquiry." ${ }^{140}$ Specifically, the court noted that while some of the policies underlying the act of state cases were implicated in this case (for example, avoidance of embarrassment to the Executive in its conduct of foreign affairs), ${ }^{141}$ the factual predicates of the doctrine were not met because the case did not require the court to pass on the validity of an official action by a foreign sovereign. ${ }^{142}$ Thus, the act of state doctrine was inapplicable, ${ }^{143}$ and the court did not need to engage in foreign policy analysis. In a future case, if the factual predicates were met, the court still would have to wade through foreign policy. But by strictly requiring that these factual predicates exist, the court preemptively limited its future forays into foreign policy in the act of state context. ${ }^{144}$

Courts should let these cases, and their rule-directed aim, be their guide. Under the current Keith standard, the content of federal law (for example, whether there is a warrant requirement) is not known until a court decides whether "undue interference" exists ${ }^{145}$-in other words, until a court does some freelance foreign policy work. While a Supreme Court decision could specify the content of federal law by applying the Keith test to determine whether there is a warrant requirement for foreign intelligence searches abroad, this specification would not "be prior to the point of judicial decision" in any meaning-

\footnotetext{
evaluate whether the national interest is best served by tax uniformity, or state autonomy.").

135 Id.

136493 US 400 (1990).

137 Id at 402 . For a discussion of Kirkpatrick in the context of the "new formalism," see Goldsmith, $70 \mathrm{U}$ Colo L Rev at 1425-27 (cited in note 21).

138 Kirkpatrick, 493 US at 404.

139 Id at 403-04 (discussing the district court's finding that a nation's motivation was at issue and the court of appeal's reversal based on the facts of the case).

140 Goldsmith, $70 \mathrm{U}$ Colo L Rev at 1426 (cited in note 21).

141 Kirkpatrick, 493 US at 406, 409.

142 Id at 406 ("Act of state issues only arise when a court must decide-that is, when the outcome of the case turns upon-the effect of official action by a foreign sovereign.").

143 Id.

144 Goldsmith, $70 \mathrm{U}$ Colo L Rev at 1426 (cited in note 21).

145 Keith, 407 US at 315.
} 
ful sense.$^{146}$ It would still flow from a standard that every court, the Supreme Court included, is unable to competently apply. A rule, on the other hand, would arise before any judicial decision in an intellectual, if not chronological, sense because it would exist independent of any court's assessment of the foreign policy merits of any particular case."

Moreover, courts could apply this rule whereas they were unable competently to apply the Keith standard. In order to decide whether it can issue a warrant in a traditional criminal context, a court must conclude that there is probable cause to believe an offense has been committed and that the warrant would target the individual or individuals who have committed the offense. ${ }^{148}$ Though different from the task of deciding whether to issue a warrant in a traditional case, the charge of the foreign intelligence case is not outside the ken of the judiciary.

Courts would simply be performing a routine legal taskassessing factual evidence to determine whether it meets a legal standard (probable cause). As the Second Circuit wrote, "While courts are not competent to formulate national policy," it is their duty to determine whether "the political branches, in exercising their power, have 'chosen a constitutionally permissible means of implementing that power.", ${ }^{149}$ In other words, while the courts lack the foreign policy expertise necessary to determine whether an undue burden exists (to formulate national policy), they are able to decide whether probable cause exists (to decide whether constitutional means were chosen).

In these cases, as with FISA cases, it would be sensible for the courts to look for probable cause that the target of the warrant had foreign intelligence information (rather than probable cause that she had committed a criminal offense). On first glance, this probable cause requirement might not appear to place any real limitations on the Executive because foreign intelligence information sounds like a manipulable concept. But, in fact, probable cause would cabin the Executive by eliminating the most egregious misuses of the power. The

146 Goldsmith, 70 U Colo L Rev at 1424 (cited in note 21).

147 One might argue that by choosing a formalist rule the court would be making a foreign policy decision - namely, to ignore foreign affairs concerns. This is true in a sense. But it would be more accurate to frame this decision as one of institutional competence rather than foreign policy. In other words, foreign policy is ignored because the Executive's built-in bias in search decisions prevents it from impartially considering such information, and the courts are not designed to judge such information, leading them to defer to the Executive. This Comment does not address the hypothetical question of whether it would be proper to consider foreign policy information if the Executive were impartial in making search decisions or if the courts were experts on formulating foreign policy.

148 Charles A. Wright, 3 Federal Practice and Procedure: Criminal \$ 670 at 708-19 (West 2d ed 1982) (providing a detailed description of the warrant process).

149 Lamont $v$ Woods, 948 F2d 825, 832 (2d Cir 1991), quoting Planned Parenthood Federation Inc v Agency for International Development, 838 F2d 649, 655-56 (2d Cir 1988). 
courts should require that, as in FISA cases, the Government provide evidence showing probable cause that the target of the warrant was not just being targeted for her views (permitted First Amendment activities), but that she was an agent of a foreign power, ${ }^{1,0}$ and the premises to be searched are owned, used, or possessed by the agent or the foreign power. ${ }^{\text {s.1 }}$ This is a real, and not insubstantial, evidentiary burden.

Of course, the courts will have discretion to determine whether probable cause exists. And if a court wants to defer to the Executive, this is where it will do so. But that does not mean that the probable cause standard does not do any work. First, it extricates the courts from foreign policy. While foreign affairs information would be relevant to a decision about probable cause in the foreign intelligence context, the court would not be forced to make an independent foreign policy assessment-it would only have to decide a legal question. As the Court underscored in Baker $v$ Carr, ${ }^{152}$ "it is error to suppose that every case or controversy which touches on foreign affairs lies beyond judicial cognizance." ${ }^{1533}$ Second, vis-à-vis the no-warrant rule, the probable cause standard beneficially shifts discretion from the Executive to courts. This shift of discretion is beneficial in the context of the Fourth Amendment because the Executive has a built-in institutional bias in favor of conducting searches, whereas the courts are neutral intermediaries between the Executive and the citizenry.

\section{B. The Warrant Rule Comports Better with the Fourth Amendment than a No-Warrant Rule}

This rule-bound inquiry would fit into existing Fourth Amendment jurisprudence. Fourth Amendment jurisprudence revolves around courts making reasonableness assessments. ${ }^{1.4}$ Courts ordinarily eschew formalism in this context because of "the infinite and unpredictable search and seizure scenarios that defy advance judicial contemplation." 1 Iss Instead, they focus on balancing liberty and order be-

15050 USC $\$ 1824(\mathrm{a})(3)(\mathrm{A})(1994)$.

15150 USC $\$ 1824(\mathrm{a})(3)(\mathrm{B})$.

152369 US 186 (1962).

153 Id at 211.

154 United States $v$ Ramirez, 523 US 65, 71 (1998) (discussing reasonableness as applied to a "no-knock" entry that resulted in the destruction of property); Pennsylvania v Mimms, 434 US 106, 108-09 (1977) ("The touchstone of our analysis under the Fourth Amendment is always 'the reasonableness in all circumstances of the particular governmental invasion of a citizen's personal security."'), quoting Terry v Ohio, 392 US 1, 19 (1968).

155 Stephen E. Hessler, Note, Establishing Inevitability without Active Pursuit: Defining the Inevitable Discovery Exception to the Fourth Amendment Exclusionary Rule, 99 Mich L Rev 238, 259 (2000). 
cause this imbues the Fourth Amendment with the flexibility it needs to meet the changing demands of the real world. ${ }^{150}$

But because courts focus on the application of the Fourth Amendment in the United States, they assume that they are capable of conducting the necessary balancing. ${ }^{157}$ If the courts are not capable of conducting the necessary balancing tests, however, as is the case with the foreign intelligence exception, then a rule is preferable. ${ }^{\mathrm{iss}}$ This is one of the insights of the rules-standards debate. ${ }^{159}$ Standards and the concomitant discretion they give the decisionmaker are relatively desirable only if the decisionmaker has sufficient knowledge from which to make an informed choice. ${ }^{160}$ If she does not, as in this case, then a rule is desirable. Choosing, in a broad sense, rules over standards leaves unanswered the question of what rule to choose-a warrant rule or a no-warrant rule.

The courts should answer this question by choosing the warrant rule because it comports better with the purposes of the Fourth Amendment - as delineated by both the Court and the Framers - than does the alternative no-warrant rule. ${ }^{161}$ It offers more protection to the citizen than the no-warrant rule because it requires the Executive to convince a neutral party, a magistrate, that a search is reasonable and limited. ${ }^{162}$ And according to the Supreme Court, "The basic purpose of [the Fourth] Amendment, as recognized in countless decisions of this Court, is to safeguard the privacy and security of individuals against

156 Meares and Harcourt, 90 J Crim L \& Criminol at 737 (cited in note 124) ("The Court's recognition and embrace of real world experience forced a rejection of the formalism characteristic of nineteenth century Fourth and Fifth Amendment decisions.").

157 See Bell $v$ Wolfish, 441 US 520, 559 (1979) (arguing that "[t]he test of reasonableness under the Fourth Amendment is not capable of precise definition. ... In each case it requires a balancing ...") (emphasis added).

158 Adrian Vermeule, Interpretive Choice, 75 NYU L Rev 74, 92 (2000) (arguing that the Court is better off deciding foreign policy questions in the aggregate rather than making an individual assessment in each case).

159 There is a wealth of literature on the rules versus standards debate. See generally Louis Kaplow, Rules versus Standards: An Economic Analysis, 42 Duke L J 557 (1992) (offering an economic analysis on whether a law should be "given content ex ante or ex post"); Kathleen $\mathrm{M}$. Sullivan, Foreword: The Justices of Rules and Standards, 106 Harv L Rev 22 (1992) (arguing that the contribution of the Reagan-Bush appointees to the Supreme Court was to move policy toward rules); Antonin Scalia, The Rule of Law as a Law of Rules, 56 U Chi L Rev 1175 (1989) (supporting the use of rules and eschewing "balancing modes of analysis"); Vermeule, 75 NYU L Rev 74 (cited in note 158) (proposing that rules are preferable to standards in an environment of empirical uncertainty due to their lower transaction costs).

160 Vermeule, 75 NYU L Rev at 92-93 (cited in note 158) ("Standards require more information and decisional competence ex post.").

161 Camara v Municipal Court, 387 US 523, 528-29 (1967) ("[A] search of private property without proper consent is 'unreasonable' unless it has been authorized by a valid search warrant.").

162 Johnson $v$ United States, 333 US 10, 14 (1948) (finding the essential protection of the Fourth Amendment to consist in the determination of a neutral magistrate that there is sufficient evidence to support a warrant). 
arbitrary invasions by government officials." ${ }^{\text {,63 }}$ This pronouncement by the Court echoes the Framers' understanding of the Fourth Amendment as a tool to limit the exercise of arbitrary discretion by members of the executive branch to decide where and whom to search. ${ }^{164}$

This is not to say that there are no serious arguments for the nowarrant rule. First, the no-warrant rule serves the same crucial purpose as the warrant rule-it frees the judiciary from making foreign policy decisions. Second, one might argue that unlike the warrant rule, it does not eliminate what may be important foreign policy concerns from the decision of whether to conduct a search. Instead, the nowarrant rule entrusts them to the Executive who has expertise in making these decisions. Moreover, the argument would continue, the events of September 11 show that foreign policy concerns matter. The ability to search someone for foreign intelligence information may save lives.

The most fundamental problem with the no-warrant rule is that it ignores the central idea behind the Fourth Amendment: a neutral party, the courts, should make decisions about searches. ${ }^{165}$ If the Executive could conduct warrantless searches for foreign intelligence information, then it would have the kind of discretion that is readily subject to grave abuses. The Government could, for example, invoke "foreign policy concerns" to justify warrantless searches of dissident or disfavored groups even if they had no real foreign intelligence information. ${ }^{166}$ Furthermore, instituting a warrant requirement would not significantly hinder the Government's ability to prevent a replay of the horrible events of September 11. The Government could still conduct the necessary foreign intelligence searches; it would just have to show probable cause that the target possessed foreign intelligence information. ${ }^{107}$ And in the event that a search were necessary to prevent imminent danger to life and limb, the Government could execute a war-

163 Camara, 387 US at 528.

164 Morgan Cloud, Pragmatism, Positivism, and Principles in Fourth Amendment Theory, 41 UCLA L Rev 199, 296 (1993) (discussing the Framers' desire to eliminate the exercise of arbitrary discretion, usually by the executive branch, in searches and seizures).

165 Johnson, 333 US at 14 (noting that to allow searches without a warrant is to "reduce the [Fourth] Amendment to a nullity and leave the people's homes secure only in the discretion of police officers").

166 The Keith Court had the same concern about warrantless domestic intelligence searches. See Keith, 407 US at 314.

167 Moreover, this probable cause standard, which is analogous to FISA's standard, is lower than the traditional probable cause standard. See Robert A. Dawson, Shifting the Balance: The D.C. Circuit and the Foreign Intelligence Surveillance Act of 1978,61 Geo Wash L Rev 1380, 1393 n 73 (1993) (noting that FISA's probable cause standard is lower because the same proof of criminal activity is not necessary). 
rantless search under the exigency exception to the Fourth Amendment.

\section{A Warrant Would Serve an Important Pre-Clearance Function}

A warrant issued after a finding of probable cause would serve the same pre-clearance function abroad that it serves domestically. Recently, in United States $v$ Verdugo-Urquidez, ${ }^{169}$ a plurality of the Supreme Court wrote that a warrant is a "dead letter outside of the United States." ${ }^{170}$ Bin Laden cited this language to show that such a warrant would be useless, and therefore an undue burden on the Executive. ${ }^{171}$ Though never explained by the plurality in Verdugo, this language presumably means that a warrant would not "authorize" a search as a matter of international law. ${ }^{172}$ For example, even if the Government were armed with a warrant from an American magistrate, it could not search a United States citizen in France without the permission of the French government. ${ }^{173}$

The Verdugo Court's narrow view of the purpose of a warrant overlooks the important limiting function a warrant plays in our system. A warrant limits the discretion of the executive in order to protect the rights of the individual; it is not simply a legal password. So, even if a warrant would not be a sufficient condition for a search, it should be a necessary one. As Justice Brennan recognized in dissent in Verdugo, "a warrant serves the same primary function overseas as it does domestically: it assures that a neutral magistrate has authorized the search and limited its scope."174 Whatever one thinks about the logic of Verdugo, its holding was limited to the application of the warrant clause to noncitizens abroad. ${ }^{175}$

168 Mincey v Arizona, 437 US 385,392-93 (1978) ("“The need to protect or preserve life or avoid serious injury is justification for what would be otherwise illegal absent an exigency or emergency."'), quoting Wayne v United States, 318 F2d 205, 212 (DC Cir 1963).

169494 US 259 (1990). This case held that the Fourth Amendment does not apply to the search and seizure by United States agents of property owned by a nonresident alien and located in a foreign country. Id at 261.

170 Id at 274.

171 Bin Laden, 126 F Supp 2 d at 276.

172 Verdugo, 494 US at 296 (Brennan dissenting) (acknowledging that a warrant from a United States magistrate would not authorize a search in a foreign country under international law, but cautioning that does not make the Warrant Clause inapplicable).

173 Without permission from the foreign government, the enforcement jurisdiction of the United States would run headlong into the customary international law norm of territorial sovereignty. See Ayaz R. Shaikh, Note, $A$ Theoretic Approach to Transnational Terrorism, 80 Georgetown L J 2131, 2159 (1992) (discussing the problem of extending one state's enforcement jurisdiction into another's because of state territorial sovereignty).

174 Verdugo, 494 US at 296 (Brennan dissenting).

175 Id at 278 (Kennedy concurring) ("The rights of a citizen, as to whom the United States has continuing obligations, are not presented by this case."). 
There are two possible paths for implementing the warrant rule: 1) the Supreme Court could implement it, or 2) the lower courts could narrowly interpret Keith to the same effect. The first path is straightforward. The Court would simply decide (as it did in Keith ${ }^{176}$ ) that there is no exception to the warrant requirement in this situation. Absent such a sea change in high Court precedent, the lower courts could implement this rule by interpreting Keith to apply only to domestic intelligence searches-given that the Court consistently distinguished domestic intelligence searches from the foreign intelligence searches. ${ }^{\mathrm{m}}$ The first path is preferable because of its finality, but the exigencies of the moment (the number of warrantless searches and the slow path to the Supreme Court) may require lower courts to shoulder the burden of moving to the new, better rule.

\section{CONCLUSION}

Since the early 1970s, the courts have intermittently misapplied the Warrant Clause to foreign intelligence searches. In 1978, FISA, for all practical purposes, took the issue out of the courts' hands. But with Bin Laden, this issue experienced a renaissance in the courts. Without missing a beat, the Bin Laden court fell back into the judiciary's old, troubled ways. The trouble is that the Keith standard binds the decision of whether to issue a warrant to a judicial analysis of foreign policy. Formally and functionally ill-equipped to analyze foreign policy, the courts have deferred to the Executive's position.

This Comment asks the courts to require, by rule, that the Executive obtain a warrant before she conducts a foreign intelligence search targeted at an American citizen overseas. By adopting this rule, the courts could both protect the Fourth Amendment right to privacy and avoid making foreign policy assessments. Moreover, this change would fit into both the burgeoning foreign affairs law doctrine of new formalism and existing criminal procedure jurisprudence. In the absence of such a change, the Sword of Damocles in the form of judicial abdication will continue to hang over the rights of American citizens overseas.

$176 \cdot$ Id at 321.

177 Id at 308, 321-22 (limiting the opinion to domestic intelligence cases and expressing no opinion as to requirements for foreign intelligence searches). 


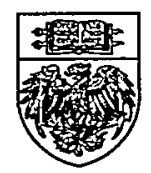

